\title{
Elt Preservice Teachers' Perceptions and Opinions on How to Integrate ICT in Language Classes
}

\author{
İlknur Yüksel \\ Assist. Prof. Dr. Eskişehir Osmangazi University, iyuksel@ogu.edu.tr

\section{Esra Eren} \\ Assist. Prof. Dr. Eskişehir Osmangazi University, eeren@ogu.edu.tr
}

This study examined ELT students' perceptions and opinions on how to integrate ICT in language classes. The participants' compromised of 97 students attending to the department of English Language Teaching in Turkey. The data of this descriptive study was collected through a questionnaire developed by the researchers. As analyzed through descriptive statistics, the findings indicated that the participants had positive perceptions towards the use of ICT and they were aware of the effectiveness of ICT tools for language teaching. Majority of the participants reported that the use of ICT would contribute not only their teaching competencies but also teaching each language skill effectively. Most of the participants agreed that the use of ICT in language classes will make language teaching fun and it will enhance the language learners' motivation so as to make learning permanent through the use of visual, audial and animated tools. It was also observed that the participants could suggest the use of different ICT tools for each language skill considering the dynamics of skills and tools.

Keywords: Technology Integration, ICT, Language Teaching, Web 2.0

Citation: Yüksel, İ., \& Eren, E. (2016). ELT Preservice Teachers' Perceptions and Opinions on How to Integrate ICT in Language Classes. Anatolian Journal of Education, 1(1), 71-88. https://doi.org/10.29333/aje.2016.115a

* The part of this study was presented at International Conference ICT in Language Teaching (4-5, June, 2015) Eskişehir Osmangazi University, Turkey. 


\section{İngilizce Öğretmenliği Bölümü Öğrencilerinin Dil Derslerinde Bit Entegrasyonuna İlişkin Algıları Ve Görüşleri}

$\mathrm{Bu}$ araştırmada İngilizce Öğretmenliği bölümünde öğrenim gören öğrencilerin dil derslerinde Bilgi ve İletişim Teknolojilerinin (BİT) entegrasyonuna ilişkin algıları ile görüşleri belirlenmeye çalışılmıştır. Çalışma grubunu 2014-2015 öğretim yılı bahar döneminde Türkiye'de bir üniversitenin İngilizce Öğretmenliği bölümünde öğrenim gören 97 öğretmen adayı oluşturmuştur. Betimsel olarak tasarlanan araştırmanın verileri araştırmacılar tarafından geliştirilen anket aracılığıyla toplanmıştır. Verilerin analizinde frekans, yüzde ve ortalama kullanılmıştır. Araştırma sonucunda öğretmen adaylarının BİT uygulamalarıyla ilgili oldukça olumlu duygu ve görüşlere sahip oldukları ve BİT araçlarının dil öğretimi için ne kadar etkili olabileceğinin farkında oldukları belirlenmiştir. Öğretmen adaylarının çoğu öğretme-öğrenme sürecinde BİT kullanımının dil eğitiminde gerek genel olarak öğretmenlik becerilerinin gelişmesinde gerekse her bir dil becerisinin etkili öğretiminde katk1 sağlayacağı yönünde görüş bildirmişlerdir. Katılımcılar BİT uygulamalarının eğlenceli ve öğrencinin aktif olmasına olanak vermesiyle öğrencilerin motivasyonlarının ve öğrenmelerinin artacağı, görselişitsel araçlarla dil öğreniminin kalıcı hale geleceği konusunda hemfikirdirler. Ayrıca, katılımcılar araçların özelliklerini dikkate alarak her dil becerisi için farklı BİT araçlarını önermektedirler.

Anahtar Kelimeler: Bilgi ve İletişim Teknolojileri (BİT), Teknoloji Entegrasyonu, Yabancı Dil Eğitimi, Web 2.0

\section{INTRODUCTION}

Information has been the invaluable treasure of the societies. The ones who attain more and more qualified information and who can use it effectively and accurately get ahead others and reached prosperity. Particularly since the mid of 20th century, technological developments have facilitated to attain, store, proceed and share information. Such developments started the information age (Kalkınma Bakanlığı, 2015).

Information and Communication Technologies (ICT) are defined as significant tools both to produce information and to share it effectively. Moreover, ICT is accepted as an important indicator of development level of the countries. The countries emphasize the use of ICT and the investments for this in their future development plans. In parallel with these trends in the world, the investments to transform to the information society in 
Turkey also increase more and more. Ministry of Education is one of the pioneering institutions that will make most of the investments on ICT (45\%) in 2016 (Kalkınma Bakanlığg1, 2016). FATIH project, abbreviated for "Movement of Enhancing Opportunities and Improving Technology Project", is the most known investment.

Educational institutions have the most responsibility to achieve these investments on ICT and to train the qualified individuals necessary for information society. The students are expected to have competencies of attaining, using, configuring, sharing information, and problem-solving as well as cooperation (ISTE [ International Society for Technology in Education], 2016; MEB, 2016). Thus, many researchers agree that integrating ICT into education will enable to achieve these learning goals and contribute to active learning (Aktaruzzaman, Shahim, \& Clement, 2011; Ertmer \& OttenbreitLeftwich, 2010; Roblyer, 2006; Wang \& Woo, 2007).

The integration of ICT are expected at many educational institutions to gain students the information and skills necessary at $21^{\text {st }}$ century (Buabeng-Andoh, 2012). In the same vein, the strategic reports and documents related with the ICT politics in Turkey support and emphasize the integration of ICT (MEB, 2016; TUBITAK, 2013). The ICT integration is mainly defined as an essential tool to achieve learning outcomes and to increase students' success (Hew \& Brush, 2007; Usluel, Mumcu, \& Demiraslan, 2007). Additionally, it is underlined that the integration of ICT is not only to acquire the update technologies but also to take into consideration the different administrative, instructional and institutional factors (Kabakçı \& Yurdakul, 2011). There are different perspectives on how to use and integrate ICT in education. While some of these perspectives emphasize the role of ICT tools to enrich learning, the others focus on the students' use of ICT effectively and integrating ICT into teaching programs (Mazman \& Usluel, 2011).

Although remarkable improvements on developing the infrastructure of ICT at schools in Turkey have recently occurred the integration of ICT into education is not so easy (Ilgaz \& Usluel, 2011). Some of the most common problems encountered at schools can be listed as financial and technical problems, teachers' limited competencies, and their attitudes and beliefs (Hew \& Brush, 2007). On the other hand, Ertmer et al. (2012) stated that the financial problems have been solved mostly. Thus, the foregrounded research topics should be teachers' beliefs on ICT and how to integrate ICT in classes (Altun, Kalayc1, \& Avc1, 2011; Ertmer \& Ottenbreit-Leftwich, 2010; Ertmer et al., 2012, Roblyer, 2006; Wang \& Woo, 2007; Tondeur, Van Braak \& Valcke, 2007).

The studies conducted on the ICT integration at schools indicated that the teachers want to use technology but they do not know how to integrate it into teaching-learning 
process so they do not use ICT (Adıgüzel \& Yüksel, 2012; Adıgüzel, Gürbulak, \& Sarıçayır, 2011; Balkı \& Saban, 2009; Bozkurt \& Cilavdaroğlu, 2011; Çakır \& Yıldırım 2009; Göktaş, Yıldırım, \& Yıldırım, 2008; Hew\& Brush, 2007; Kurt et al., 2013; Usluel et al., 2007). It was also determined that technology is mostly used to transmit information rather than to support students' high order thinking skills (Seferoğlu, Akbıyık, \& Bulut, 2008; Ertmer, 2005; Göktaş et al., 2008; Hakverdi \& Dana, 2012; Usluel et al., 2007; Yildırım, 2007). For effective integration, teachers should choose efficient and appropriate tools and methods considering students' needs, besides they have to develop new teaching strategies (Demiraslan \& Usluel, 2008). Thus, teachers need guidance on how to integrate ICT in order to facilitate meaningful learning for real-life situations and interrelated information sharing (Ertmer \& Ottenbreit-Leftwich, 2010). For ICT integration to facilitate student-centered learning, teachers should have these competencies (Cennamo, Ross, and Ertmer, 2010):

- Identify which technologies are needed to support specific curricular goals

- Specify how the tools will be used to help students meet and demonstrate those goals

- Enable students to use appropriate technologies in all phases of the learning

- Process including exploration, analysis, and production

- Select and use appropriate technologies to address needs, solve problems, and resolve issues related to their own professional practice and growth.

The web 2.0 tools that are nowadays of significant component of ICT provide access to powerful communication and collaboration tools almost a "non-issue" for any teacher who has Internet access in his/her classroom. A key characteristic of Web 2.0 is the role played by users in creating, using, and sharing resources (Ertmer at al., 2012). The Web 2.0 tools that can be effectively used in education can be listed as Social bookmarking (Delicious, Diigo, etc.), Wikis (Wikispaces, etc.), Shared document creation (Google Docs, etc.), Blogs (Blogger, Wordpress, etc.), Microblogging (Twitter, etc.), Presentation tools (Prezi, Slideshare, etc.), Image creation and editing (Pixlr, Gliffy, etc.), Podcasting and the use of audio (Audacity, Voicethread, etc.), Screen recording (Camstudio, Jing, etc.), Mindmapping (Mindmeister, etc.), Digital storytelling (Toondoo, GoAnimate, Powtoon) can be categorized (Bower, Hedberg, \& Kuswara, 2010).

For language teaching, the integration of ICT is also supported and the use of ICT for language skills namely reading, writing, speaking and listening has become widespread as an effective tool that facilitate effective real-life learning (Taşkıran, Koral, \& Bozkurt, 2015). Several ICT tools provide opportunities to both teachers and students 
such as progress in students' pace, autonomy and alternative activities for teachers (Sarıçoban \& Bakla, 2012). For the effectiveness of these tools, Leask (2001) underlined that technology should be integrated seamlessly into the overall activity in the class and and it should be also used as a cross-curricular tool that supports language learning. As mentioned so far, teacher has a key role in the integration of ICT in learning and teaching process, especially language learning. Thus, during language teacher training, the integration of ICT should be emphasized to ensure that preservice teachers have necessary competencies for ICT integration for their future profession. The first step for such professional growth is to determine their perceptions and opinions and develop appropriate teacher training strategies to teach them how to integrate ICT.

\section{METHOD}

\section{Design \& Aim of the Study}

This study was designed through survey model and descriptive method was adapted in order to determine ELT preservice teachers' perceptions and opinions on how to integrate ICT in language classes. On this purpose, the following research questions were addressed:

- What are the ELT pre-service teachers' perceptions on the use of ICT?

- What are the ELT pre-service teachers' opinions on why and how to integrate ICTin language classes?

\section{Participants}

The participants of the study compromised of 97 students attending to the department of English Language Teaching (ELT). The participants were selected through purposeful sampling method. In this method, the samples that are the most appropriate to the aim of the study are selected (Balc1, 2006). Out of the participants, 74 were female, 24 of them were male. In terms of year, 76 of the participants attended to $1^{\text {st }}$ year while 21 were $2^{\text {nd }}$ year students.

\section{Research instrument}

As data collection instrument, the questionnaire developed by the researchers were used. While developing the questionnaire, firstly the related literature was reviewed and possible items were written. After the first draft was presented to the experts necessary corrections and developments were conducted and it was piloted.

The final version consists of four sections. At the first section, there are 22 items questioning the ELT preservice teachers' perceptions on the integration of ICT on 5- 
point Likert scale. At the second section, there is a matrix on which ICT tools can be used for which language skill (reading, writing, listening, speaking, grammar, vocabulary). At the third section, the participants were again asked to range the ICT tools in terms of effectiveness. Lastly, the students were asked which ICT tools they would integrate in their future career.

\section{Research procedures}

The preservice teachers participated to the study received training on the use of ICT tools within the scope of Computer II during 14 weeks. During this period pre- service teachers were introduced several tools for content development including: presentation tools, video creation tools, digital story-telling tools, e-book preparation tools, communication and collaboration tools such as Google Documents and Blogs. Many project works were conducted either individually or as a group work at labs and as homework. Their in-class and outside of class assignments were graded regularly and their grades were declared in the class' Learning Management System (LMS), Moodle site. The ICT tools such as presentation, film, animation, mind-mapping and so on that students can easily and practically prepare were chosen (Eren, Yurtseven Avc1 \& Seçkin Kapucu, 2014). Some of these tools are computer based (voice recording, paint, movie maker, camtasia, hotpotatoes) and the others are web-based. The ICT tools that were studied in the course are illustrated in the following Figure 1.

Figure 1: The ICT tools referred and used in this study
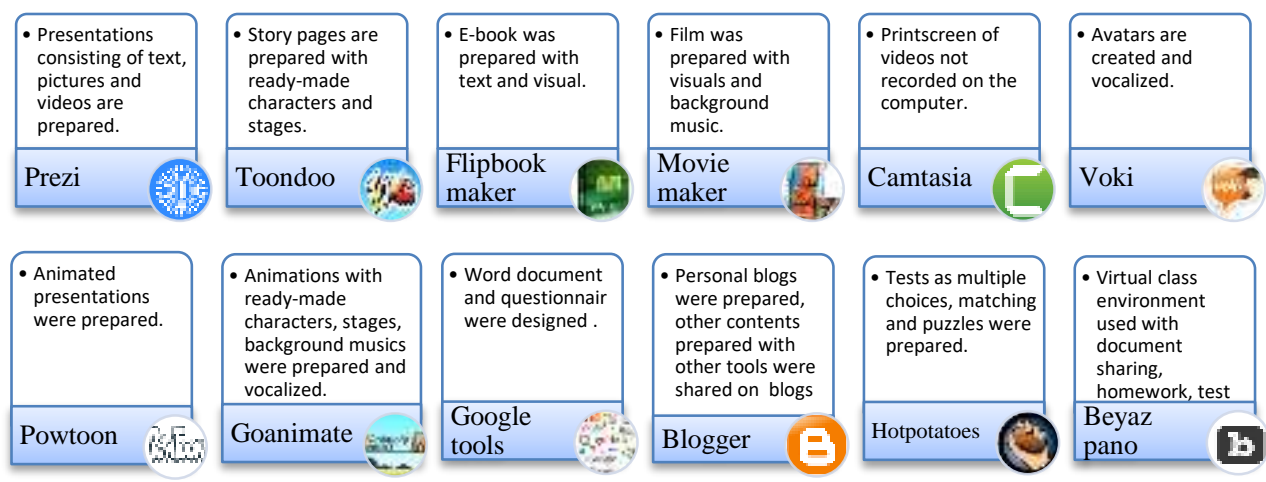

The main focus of their implementations and projects was on English language teaching. So, students were guided to design applications on a chosen English language subjects. However, in the scope of the course, the main principles of applications, informatics ethics, social webs (social bookmarking etc), online game-based learning 
platform (Kahoot), concept mapping (Gliffy) and the other instructional sources to prepare e-content were also explained and discussed.

In addition to theoretical support and practical motivation for the participants' skills to develop the tools on project works, the integration of ICT tools were fostered when participants were asked to apply the ICT tools that they developed for language teaching in their language teaching methodology classes. These participants were asked to make demo lessons on a language subject at their methodology courses, in their demos they were asked to choose and develop any of the ICT tools that they have studied at Computer II course. In that way, it was ensured that the participants would have an idea how to develop and integrate ICT in their language classes. The data for this study was collected after the $2^{\text {nd }}$ year students' ICT integrated language teaching demos. It was considered as a the best way to learn about their perceptions and opinions of the integration of ICT after they had just integrated.

\section{Data analysis}

After the data of the study was collected, descriptive statistics analyses were conducted. Thus, the mean and standard deviation of the responses were calculated. The score ranges were calculated as strongly disagree $=1.00-1.80$; disagree $=1.81-2.60$; No Idea $=$ 2.61-3.40; Agree $=3.41-4.20$ and Strongly Agree $=4.21-5.00$.

\section{FINDINGS}

This section reports the findings of the study referring to each research question. Firstly, the findings of the participants' perceptions on the use of ICT in language classes will be presented, then, the participants' opinions on why and how to integrate ICT will be explained through descriptive statistics. The findings related to the integrate ICT for each language skill will be illustrated with tables and graphs. At last, the findings that report the participants' future plans to use ICT in their actual classes will be presented.

\section{ELT Preservice Teachers' Perceptions on the Integration of ICT}

The present study firstly questioned the ELT preservice teachers' perceptions on how to integrate ICT technologies in language classes through the first part of the questionnaire. The participants' answers to the five-point likert scale rating from strongly disagree to strongly agree were analysed. The mean values of the participants' answers are presented in Table 1 in the following.

Table 1 
Participants' perceptions on the use of ICT in the language class

\begin{tabular}{lc}
\hline & $\bar{X}$ \\
\hline While using ICT; & \\
\hline I belived that they would help me become more effective teacher. & 4.42 \\
\hline I agreed that technology should be integrated into teaching. & 4.33 \\
\hline I found it beneficial. & 4.09 \\
\hline I had fun. & 3.53 \\
\hline I loved my profession. & 3.35 \\
\hline My self-confidence increased. & 3.13 \\
\hline I got anxious. & 2.86 \\
\hline I had difficulty. & 2.76 \\
\hline I found it unnecessary. & 2.07 \\
\hline
\end{tabular}

As Table 1 indicates the majority of the participants believed that ICT tools would help them become more effective teachers (mean =4,42). Additionally, the participants mostly agreed that technology should be integrated into teaching (mean $=4.33$ ). The distribution of the findings in Table $\mathrm{X}$ indicates that the participants' negative perceptions on ICT integration have very low means. Few participants found ICT use as unnecessary $($ mean= 2.07).

\section{ELT Preservice Teachers' Opinions on Why and How to Integrate ICT}

After the participants' perceptions on ICT integration in language teaching were determined, their opinions on why and how to integrate ICT were questioned. In that way, it was aimed to reveal the participants' actual beliefs and further practical ideas. The 22 items questioning the participants' opinions were analyzed and the most frequent and least frequent answers are presented in Table 2.

Table 2

Participants' opinions on why to integrate ICT in language classes

\begin{tabular}{lc}
\hline & $\bar{X}$ \\
\hline 1. It makes language teaching fun. & 4.45 \\
\hline 2. It makes language teaching easy. & 4.39 \\
\hline 3. It makes learning permanent. & 4.38 \\
\hline
\end{tabular}




\begin{tabular}{lc}
\hline 4. Sharing learning materials becomes easier. & 4.36 \\
\hline 5. It makes language teaching effective. & 4.35 \\
\hline 6. It increases students' productivity and creativity. & 4.34 \\
\hline 7. It increases students' motivation. & 4.31 \\
\hline 8. It requires more effort and time. & 4.25 \\
\hline 9. It increases the students' participation. & 4.24 \\
\hline 10. It facilitates collaborative learning. & 4.16 \\
\hline 11. It promotes critical-thinking. & 4.05 \\
\hline 12. It increase teacher-student interaction. & 4.02 \\
\hline 13 It is a waste of time. & 2.02 \\
\hline
\end{tabular}

When the participants were asked on why ICT should be integrated in language teaching, the majority of the participants agreed that ICT makes language teaching fun (mean= 4.45) and easy (mean= 4.39). Thus, it can be claimed that most of the participants are aware that ICT integration is a good way to draw language learners' attention and make language activities fun that could facilitate student involvement through animated and interesting content tools. Furthermore, the participants reported that the integration of ICT in language class makes learning permanent (mean= 4.38). Permanent learning is the desired outcome of language teaching, thus preservice teachers agreed that ICT integration is one of the best way to reach this outcome. Only few participants thought that the use of ICT is a waste of time (mean=2.02), thus they thought there is no reason to integrate ICT.

\section{Language Skill based ICT Integration}

Different from many studies in the literature, this study examined ICT integration in terms of language skills from the preservice teachers' views. Such questioning could inform about how these preservice teachers would actually integrate ICT in the language classes because language teaching is multidimensional covering different language skill dynamics. Language teaching would be more effective when teachers design their lessons considering these dynamics and integrate the appropriate materials and ICT tools for each skill. Thus, through the matrix on which ICT tool for which language skill in the questionnaire, it was aimed to reveal whether the preservice teachers have such awareness and whether they could differentiate ICT tool in terms of features of tools and language skill dynamics. 
The findings of the matrix are illustrated in the graphs as language skill based in the following. The figures are given as percentages for each ICT tool preferred by the participants for each language skill. Firstly, the participants' answers on which ICT tool is the most effective for reading skill are illustrated in Graph 1.

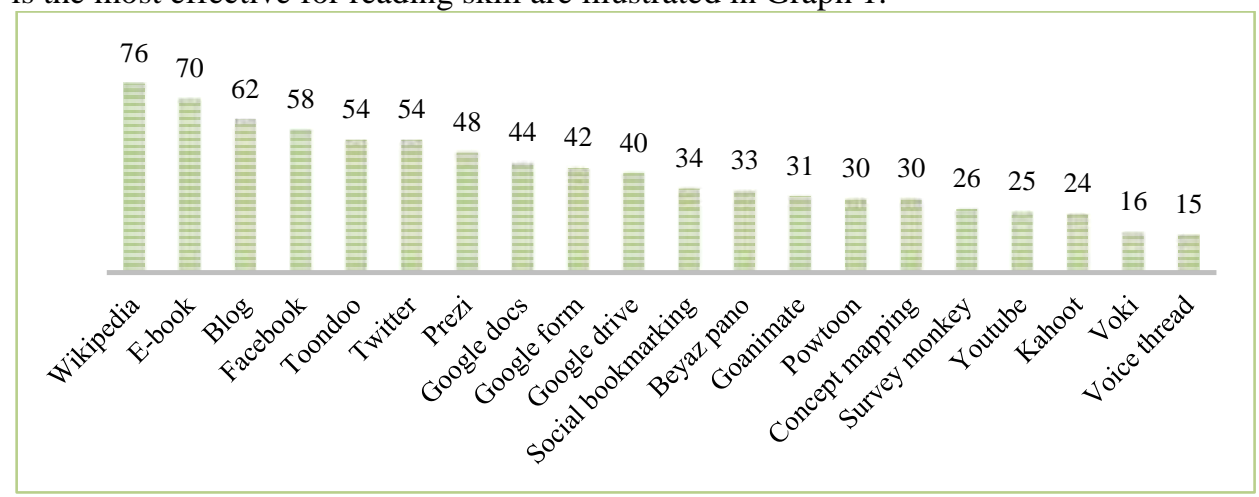

Graph 1. The Distribution of Favorite ICT Tools for Reading Skill

When the percentages illustrated in Graph 1are examined, it can be seen that majority of the participants agreed on the effective use of Wikipedia (76\%) and E-book (70\%) for reading skill. They were followed by the high percentage of Blog use $(62 \%)$. Social network tools Facebook (58\%) and Twitter (54\%) were also suggested as the effective tools to teach and support reading skill.

For writing skill, which is seen as challenging skill for many language learners, preservice teachers suggested the integration of the following ICT tools as in Graph 2.

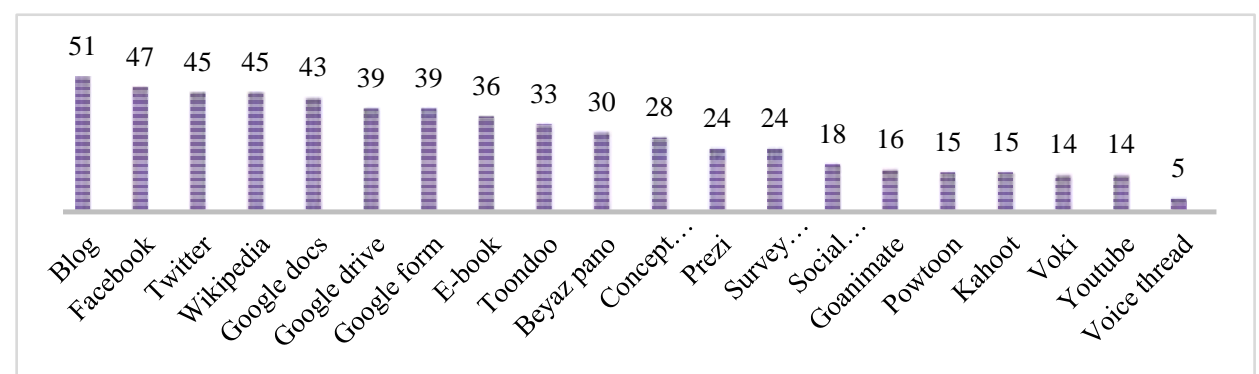

Graph 2. The Distribution of Favorite ICT Tools for Writing Skill

For writing skill, the participants also chose the use of Blogs (51\%). The participants preferred social network tools such as Facebook (47\%), Twitter (45\%) to improve writing skill as well. Wikipedia (45\%) was also suggested as an effective tool to improve writing skill. 
While for reading and writing skill, the participants preferred similar ICT tools, for vocabulary learning and teaching, they varied their choices. The answers are as follows in Graph 3.

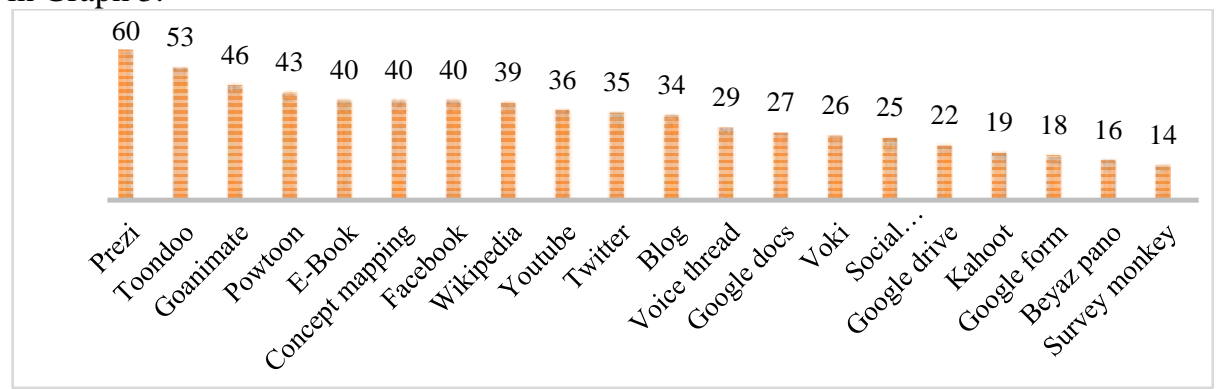

Graph 3. The Distribution of Favorite ICT Tools for Vocabulary

The most frequent answer for vocabulary teaching is Prezi (60\%) and it is followed with Toondoo (53\%), Goanimate(46\%) and Powtoon (43\%). Again, E-book (40\%) was suggested as an effective tool for vocabulary teaching as for reading skill. The distribution of the answers indicated that the preservice teachers were aware of the fact that for effective vocabulary learning, learners should be exposed to different vocabulary as in E-book and vocabulary should be in good and interesting context as possible in Goanimate, Toondoo, Prezi.

For grammar, which is the most studied and referred language skill,similar results were also observed. The distribution is given in Graph 4.

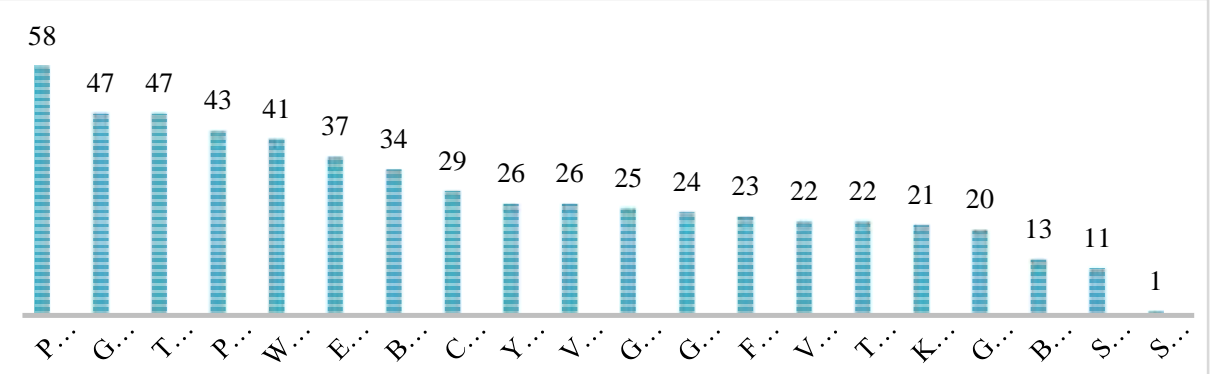

Graph 4. The Distribution of Favorite ICT Tools for Grammar

Again, a presentation tool Prezi (58\%) was suggested by $58 \%$ of the participants. Almost half the participants agreed to use Goanimate and Toondoo (47\%) to teach grammar in language classes. Different from other skills, for both vocabulary and grammar teaching, Concept mapping was moderately suggested by the participants. The 
distribution again showed that the preservice teachers preferred graphical and animation tools mostly.

Another challenging skill for language learners is listening since learners have difficulty with following the recorded scripts and authentic texts. The participants preferred to use the following ICT tools in their future listening lessons, as illustrated in Graph 5.

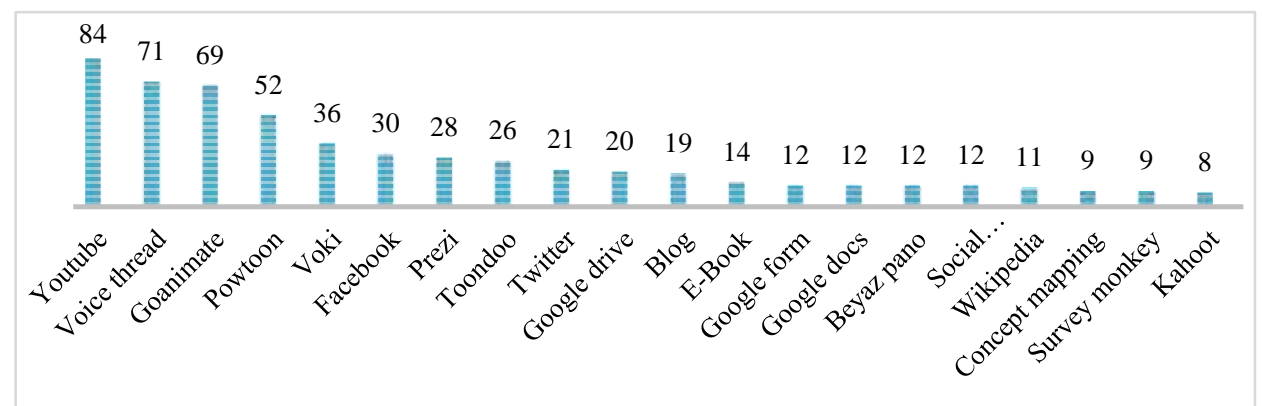

Graph 5. The Distribution of Favorite ICT Tools for Listening Skill

For listening skills, the participants mostly agreed on the use of Youtube (84\%). This video sharing tool can provide a variety of real-life video which could be used as a good source for listening activities. The results showed that the preservice teachers are aware of the potential of this tool for this skill. As it can be seen in the following graph, the use of Voicethread (71\%) and Goanimate (69\%) were other favorite tools.

As the last language skill, the participants' opinions on which ICT tools can be used effectively for teaching speaking were asked. The findings are in Graph 6.

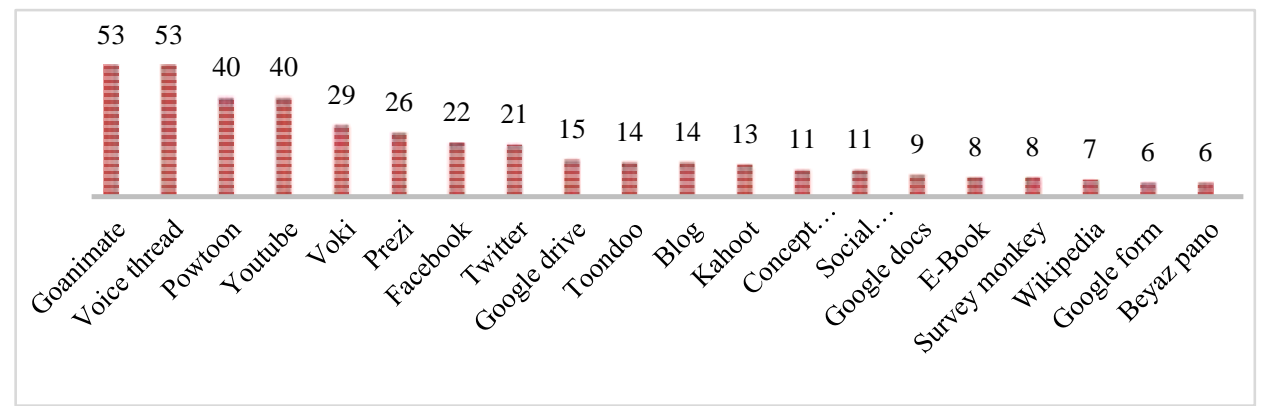

Graph 6. The Distribution of Favorite ICT Tools for Speaking Skill

The distribution of their answers indicated that Goanimate and Voicethread (53\% for each) were equally preferred by more than half of the participants. They were followed by Powtoon and Youtube (40\%) with the same percentages. The findings showed that 
the participants rated many different tools so rather than focusing on one or two tools they varied the tools.

When the overall results on the participants' answers on language skill based ICT tools are reconsidered, it could be concluded that the participants seemed to be aware of the different features of tools that can address to different dynamics of language skills. Thus, they chose the tools for language skills effectively. Rather than one or two tools, they varied their choices. Animated and graphical tools were the most favorite as well as social network tools.

\section{Future Plans on ICT Integration}

The preservice teachers in this study were also asked to rate which tool they want to use in their future career most. In that way, it was aimed to determine their tendencies on the integration of ICT tools. The frequencies were given in the following Table 3.

Table 3

ICT tools that participants plan to use in their future career

\begin{tabular}{ll}
\hline & $\mathrm{f}$ \\
\hline Goanimate & 87 \\
\hline Youtube & 76 \\
\hline Prezi & 68 \\
\hline Powtoon & 58 \\
\hline Wikipedia & 57 \\
\hline Blog & 54 \\
\hline Toondoo & 52 \\
\hline E-book & 48 \\
\hline
\end{tabular}

In their future career, most of the students plan to use Goanimate $(87 \%)$ in their language classes. It is followed by Youtube (76) with a high frequency and Prezi (68\%). Additionally, the participants envisioned that they will use Powtoon (58\%) and Wikipedia $(57 \%)$ in their classes. 


\section{CONCLUSION \& DISCUSSION}

The overall findings indicated that ELT preservice teachers participated in this study had positive perceptions on the integration of ICT. This result is consistent with the similar studies conducted in Turkey (Hismanoğlu, 2012; Aslan \& Zhu, 2015). Moreover, the results pointed out that the ELT preservice teachers in this study are aware of the effectiveness of ICT use in language classes. They mostly agreed that the integration of ICT tool would contribute their teaching as such integration would make language teaching and learning fun and easy. Erguvan (2014) also underlined the same findings about the positive contribution of ICT integration to students' motivation and teaching process, thus teachers' enthusiasm. The participants of this study also underlined that ICT integration would make learning permanent. As a support for this finding, Leask (2001) claimed that learning becomes more successful when ICT is integrated seamlessly. Thanks to different benefits of ICT integration such as scaffolded learning, immediate feedback, variety of audial and visual materials etc, language learning is fostered.

Different from the similar studies in the literature, the present study addressed to a neglected research area; language skill based ICT integration. It was aimed to examine the participants' awareness of the potential of ICT tools for each language skill. The results also showed that they can discriminate the different function and potential of each ICT tools for different language tools. They could plan to use ICT to improve their teaching qualities and motivating their students for each language skill. In terms of favorite ICT tools, the participants' answers varied according to the characteristics of tool and language skill. While for receptive skills, namely reading and listening, the tools that provide effective and comprehensible language and input such as Wikipedia, E-books, Youtube and Voicethread were suggested by the learners, for more productive skills such as writing and speaking, the tools that motivate and enable learners to use and produce language were preferred by the participants, for instance, Blogs and Goanimate. The wide range of ICT tools suggested by the participants were also referred in BaeSon's article (2011) as effective for language skill teaching.

The participants envisioned to use the similar ICT tools in their future teaching. Again animated and social network tools were preferred by the participants. Considering the highest frequencies on the tools, it could be claimed that the participants are eager to integrate these tools in the future as well.

\section{IMPLICATIONS}

Considering the result of this study, some research and pedagogical implications can be suggested. Firstly, it should be emphasized that the questionnaire developed by the 
researchers for this study was the first attempt to determine ELT pre-srevice teachers' perceptions and opinions. The content of the questionnaire can be developed and it could be applied to a larger group for the sake of higher reliability and validity. Additionally, to examine how preservice teachers integrate ICT in the actual language classrooms, similar studies could be conducted with $4^{\text {th }}$ year students who have teaching practice courses. For the pedagogical implications, it can be suggested that the use of ICT should be emphasized throughout language teaching methodology courses in teacher education. Integration of ICT into language teaching should be emphasized and exemplified considering specific language skills.

\section{REFERENCES}

Adıgüzel, A., \& Yüksel, İ. (2012). Öğretmenlerin Öğretim Teknolojileri Entegrasyon Becerilerinin Değerlendirilmesi: Yeni Pedagojik Yaklaşımlar İçin Nitel Bir Gereksinim Analizi. Necatibey Ë̆itim Fakültesi Elektronik Fen ve Matematik Eğitimi Dergisi (EFMED), 6(1), 265-286.

Adıgüzel, T., Gürbulak, N., \& Sarıçayır, H. (2011). Akıllı tahtalar ve öğretim uygulamaları. Mustafa Kemal Üniversitesi Sosyal Bilimler Enstitüsü Dergisi, 8(15), 457 $-471$.

Aktaruzzaman, M., Shahim, R., \& Clement, K. (2011). Trends and issues to integrate ICT in teaching learning for the future world of education. International Journal of Engineering \& Technology, 11(3), 114-119.

Altun, S. A., Kalayci, E., \& Avci, U. (2011). Integratıng ict at the faculty level: A case study. Turkish Online Journal of Educational Technology, 10(4), 230-240.

Aydın, H., \& Zhu, C. (2015). Pre-Service Teachers' Perceptions of ICT Integration in Teacher Education in Turkey. TOJET, Vol. 14 (3). 97-110

Balc1, A. (2006). Sosyal Bilimlerde Araştırma: Yöntem, Teknik ve Illkeler. Ankara: PegemA Yayincilik.

Balkı, E., \& Saban, A. (2009). Öğretmenlerin bilişim teknolojilerine ilişkin algıları ve uygulamalar: ÖzelEsentepe İlköğretim Okulu. İlköğretim Online, 8(3), 771-781.

BaeSon, J. (2011). Online Tolls for Language Learning. TESL-EJ, Vol. 15(1). 1-10.

Bower, M., Hedberg, J. G., \& Kuswara, A. (2010). A framework for Web 2.0 learning design. Educational Media International, 47(3), 177 - 198.

Bozkurt, A.K., \& Cilavdaroğlu, A. K. (2011). Matematik ve sınıf öğretmenlerinin teknolojiyi kullanma ve derslerine teknolojiyi entegre etme algıları,Kastamonu Eğitim Dergisi, 19(3), 859-870. 
Buabeng-Andoh, C. (2012). Factors influencing teachers' adoption and integration of information and communication technology into teaching: A review of the literature.International Journal of Education and Development using Information and Communication Technology (IJEDICT), 8(1), 136-155.

Cennamo, K. S., Ross, J. D., \& Ertmer, P. A. (2010). Technology integration for meaningful classroom use: A standards-based approach. Belmont, CA: Wadsworth, Cengage Learning.

Çakır, R., \& Yıldırım, S. (2009). Bilgisayar öğretmenleri okullardaki teknoloji entegrasyonu hakkında ne düşünürler? İlköğretim Online, 8(3), 952-964.

Demiraslan, Y. \& Usluel, Y. K. (2008). ICT integration processes in Turkish schools: Using activity theory to study issues and contradictions. Australasian Journal of Educational Technology, 24(4), 458-474.

Eren, E., Yurtseven-Avcı, Z., \& Seçkin-Kapusuz, M. (2014). Developing a scale for competencies and perceptions of necessity about using practical tools for content development. Journal of Theory and Practice in Education, 10(5), 1177-1189.

Erguvan, D. (2014). Instructors' perceptions towards the use of an online instructional tool in an academic English setting in Kuwait, TOJET, 13 (1). 115-130.

Ertmer, P. A. (2005). Teacher pedagogical beliefs: The final frontier in our quest for technology integration? Educational Technology Research and Development, 53(4), $25-39$.

Ertmer, P.A., \& Ottenbreit-Leftwich (2010). Teacher technology change: How knowledge, confidence, beliefs, and culture intersect. Journal of Research on Technology in Education, 42 (3),255-284.

Ertmer, P.A., Ottenbreit-Leftwich, A.T., Sadık, O., Sendurur, E, \& Sendurur, P. (2012). Teacher beliefs and technology integration practices: A critical relationship. Computers \& Education, 59, 423-435.

Göktaş, Y., Yıldırım, Z., \& Yıldırım, S. (2008). The keys for ICT integratıon in k-12 education: teachers' perceptions and usage. H. U. Journal of Education, 34(1), 127-139.

Hakverdi, M., \& Dana, T. M. (2012). Exemplary science teachers' use of technology. The Turkish Online Journal of Educational Technology, 11(1).

Hew, K., \& Brush, T. (2007). Integrating technology into K-12 teaching and learning: Current knowledge gaps and recommendations for future research. Educational Technology Research and Development, 55(3), 223-252.

Hismanoglu, M. (2012). Prospective EFL Teachers' Perceptions of ICT Integration: A Study of Distance Higher Education in Turkey. Educational Technology \& Society, 15 (1), 185-196. 
Ilgaz, H., \& Usluel, Y. (2011). Öğretim sürecinde bit entegrasyonu açısından öğretmen yeterlikleri ve mesleki gelişim. Eğitim Bilimleri ve Uygulama, 10 (19), 87-106.

ISTE (International Societyfor Technology in Education). (2016). The 2016 iste standards for students. Retrieved 7 November, 2016 from https:/www.iste.org/ standards/standards/for-students-2016.

Kabakçı Yurdakul, I. (2011). Öğretmen adaylarının teknopedagojik öğretim yeterliklerinin bilgi ve iletişim teknolojilerini kullanımları açısından incelenmesi. Hacettepe Üniversitesi Ĕ̈itim Fakültesi Dergisi, 40, 397-408.

Kalkınma Bakanlığı (2015). 2015-2018 Bilgi toplumu stratejisi ve eylem planı. Retrieved 4 November, 2016 from http://www.bilgitoplumustratejisi.org/tr

Kalkınma Bakanlığı (2016). Kamu bilgi ve iletişim teknolojileri yatırımları. Retrieved 4 November, 2016 from http://www.bilgitoplumu.gov.tr/wp-content/uploads/ 2016/09/ Kamu_BIT_Yatirimlari_2016.pdf.

Kurt, A. A., Kuzu, A., Dursun, O. O., Güllepınar, F., \& Gültekin, M. (2013). FATİH projesinin pilot uygulama sürecinin değerlendirilmesi: Öğretmen görüşleri. Journal of Instructional Technologies \& Teacher Education, 2(1).

Leask, M. (Ed.) (2001) Issues in teaching using ICT. London: Routledge Falmer

MEB (2016). 2015-2019 Stratejik Planı, 4 November, 2016 from http://mek2.meb.gov.tr/document/meb_strateji_belgesi.pdf

Roblyer, M. D. (2006). Integrating Educational Technology into Teaching (2nd Edition). Upper Saddle River, N.J: Prentice Hall.

Sarıçoban, A., \& Bakla, A. (2012). Yabancı dil eğitiminde teknoloji kullanımı. A. Sarıçoban \& Z. M. Tavil (Ed.). Yabancı dil öğretiminde öğretim teknolojileri ve materyal tasarımı. Ankara: Anı Yayıncılık.

Seferoğlu, S. S., Akbıyık, C., \& Bulut, M. (2008). İlköğretim öğretmenlerinin ve öğretmen adaylarının bilgisayarların öğrenme/öğretme sürecinde kullanımı ile ilgili görüşleri. Hacettepe Üniversitesi Eğitim Fakültesi Dergisi, 35, 273-283.

Tondeur, J., Van Braak, J., \& Valcke, M. (2007). Curricula and the use of ICT in education: two worlds apart? British Journal of Educational Technology, 38(6), 962976.

TUBITAK (2013). 2013-2017 Stratejik planı, Retrieved 4 November, 2016 from http://www.tubitak.gov.tr/sites/

default/files/tubitak_2013_2017_stratejik_plani.pdf 
Taşkıran, A., Koral, E., \& Bozkurt, A. (2015). Artırılmış gerçeklik uygulamasının yabancı dil öğretiminde kullanılması. Akademik Bilişim Konferansı, 4-6 Şubat, Anadolu Üniversitesi, Eskişehir.

Usluel, Y. K., Mumcu, F. K., \& Demiraslan Y. (2007). Öğrenme-öğretme sürecinde bilgi ve iletişim teknolojileri: öğretmenlerin entegrasyon süreci ve engelleriyle ilgili görüşleri. Hacettepe Üniversitesi Ĕ̆itim Fakültesi Dergisi, 32, 164-179.

Wang, Q.,\& Woo, H. L. (2007). Systematic planning for ICT integration in topic learning. Journal of Educational Technology \& Society, 10 (1).

Y1ldırım, S. (2007). Current utilization of ICT in Turkish basic education schools: a review of teacher's ICT use and barriers to integration. International Journal of Instructional Media. 34(2), 171-186. 